\section{Discussion}

Copper deficiency has been noted in infants of low birthweight, in malnourished babies, in infants fed with a milk formula of low copper content, in patients receiving prolonged parenteral nutrition or alkali medication for renal acidosis, or on long-term zinc therapy. All these causes could be excluded in our patient and in his family.

The face and the curly hair of the propositus suggested Menkes's syndrome. However, this inherited copper deficiency is characterised by severe neurological deterioration leading to death by 3 to 4 years, by pili torti, tortuosity of arteries, and decreased caeruloplasmin levels. None of these features was found in our patient, and in Menkes's syndrome oral administration of copper is generally ineffective. ${ }^{2}$ Considering the normal mental development and the normal caeruloplasmin levels of the child, his condition does not correspond to the 'mild form of Menkes's syndrome' ${ }^{3}$ nor does it correspond to so called pseudo-Menkes's syndrome. ${ }^{45}$

We were not able to clarify the mechanism of copper deficiency in the family reported here. Excessive renal loss of copper and insufficient dietary intake could be ruled out, and the underlying cause is probably a defect in the absorption of copper. Considering the mild and reversible symptoms the mechanism must certainly differ from that of true Menkes's syndrome. ${ }^{6}$ 7
The inheritance of copper deficiency in the family examined may represent an autosomal or an $\mathrm{X}$ linked dominant trait.

\section{References}

1 Sass-Kortsak A, Bearn A G. Hereditary disorders of copper metabolism. In: Stanbury J B, Wyngaarden J B, Fredrickson D S, eds. The metabolic basis of inherited $\vec{\circ}$ disease, fourth edition. New York: McGraw-Hill, 1978: 1090-126.

2 Williams D M, Atkin C L, Frens D B, Bray P F. Menkes o kinky hair syndrome: studies of copper metabolism and long term copper therapy. Pediatr Res 1977; 11: 823-6.

3 Procopis P, Camakaris J, Danks D M. A mild form of Menkes steely hair syndrome. J Pediatr 1981; 98: 97-9.

4 Calderon R, Gonzalez-Cantu N. Kinky hair, photosensitivity, broken eyebrows and eyelashes, and nonprogressive mental retardation. J Pediatr 1979; 95: $\infty$ 1007-8.

5 Dinno N D, Yacoub U, Holmes W, Weisskopf B. Letter: Pseudo-Menke syndrome. J Pediatr 1981; 99: 325.

6 Dobrescu O, Larbrisseau A, Dubé L-J, Weber M L. Trichopoliodystrophie, ou la maladie de Menkes. Can Med Assoc J 1980; 123: 490-7.

7 Onishi T, Suzue J, Nishikawa K, Muramatsu M, Miyao M. Nature of copper and zinc compounds in tissues from a patient with Menkes kinky hair syndrome. Eur $J$ Pediatr 1981 ; 137: 17-21.

Correspondence to Dr K Méhes, Department of Paediatrics, County Hospital, Györ, Pf. 92, H-9002, Hungary.

Reccived 7 April 1982

\title{
Pseudohypoaldosteronism. Response to long-term treatment with indomethacin
}

\author{
M BOMMEN AND C G D BROOK \\ Department of Paediatrics, Middlesex Hospital, London
}

SUMMARY A 6-month-old boy presented with features of pseudohypoaldosteronism. Considerable quantities of supplemental sodium failed to compensate his natriuresis but indomethacin, a prostaglandin inhibitor, greatly reduced his sodium requirement. Treatment was maintained for 9 months when re-evaluation showed him to be dependent on indomethacin for satisfactory control.

A boy of consanguineous Saudi-Arabian parents, birthweight $3 \mathrm{~kg}$, presented from a few weeks of age with lethargy, vomiting, recurrent hyponatraemic, hyperkalaemic dehydration (for example serum sodium $109 \mathrm{mmol} / 1$, potassium $7 \mathrm{mmol} / \mathrm{l}$ ). There was no response to $15 \mu \mathrm{g} / 24 \mathrm{~h} 9 \alpha$-fludrocortisone or to $2 \mathrm{mg} / 24 \mathrm{~h}$ DOCA but large supplements of sodium corrected the biochemical abnormalities.

He was referred to us aged 6 months, weighing $4.8 \mathrm{~kg}$. Apart from a slightly raised $(110 / 65 \mathrm{mmHg})$ blood pressure (BP) his clinical condition was normal. The principal biochemical findings are shown in the Table. Levels of urinary urea, creatinine, calcium, and phosphate, and amino-acid excretion were normal.

During a vomiting, hyponatraemic episode his resistance to $30 \mu \mathrm{g} / 24 \mathrm{~h} \quad 9 \alpha$-fludrocortisone was demonstrated and it was with difficulty that the 
Table Biochemical findings at age 6 months

\begin{tabular}{|c|c|c|c|}
\hline \multirow[t]{2}{*}{ Investigation } & \multicolumn{2}{|l|}{ Sodium } & \multirow[t]{2}{*}{ Normal } \\
\hline & Depleted & Replete & \\
\hline \multicolumn{4}{|l|}{ Serum } \\
\hline Sodium (mmol/1) & 120 & 135 & $132-135$ \\
\hline Potassium (mmol/1) & 7 & 4 & $3 \cdot 3-4 \cdot 5$ \\
\hline Urinary sodium (mmol/l) & \pm 160 & \pm 150 & $<30$ \\
\hline sodium: potassium ratio & $3 \cdot 2$ & $3 \cdot 4$ & 3 , but $<1$ in hyperaldosteronism \\
\hline Salivary sodium $(\mathrm{mmol} / \mathrm{l}) \mathrm{fed}$ & $?$ & 23 & $20-45$ \\
\hline sodium: potassium ratio & & 0.78 & $0 \cdot 3-1 \cdot 0$ \\
\hline Sweat sodium $(\mathrm{mmol} / \mathrm{l})$ & $?$ & 17 & $<60$ \\
\hline sodium: potassium ratio & ? & $1 \cdot 54$ & \pm 3 \\
\hline Wet faeces $(\mu \mathrm{mol} / \mathrm{g})$ & ? & 25 & \pm 30 \\
\hline Plasma ACTH (ng/l) at $0800 \mathrm{~h}$ & ? & 54 & $<60$ \\
\hline at $2400 \mathrm{~h}$ & ? & 36 & $<10$ \\
\hline Cortisol $(\mathrm{nmol} / \mathrm{l})$ at $0800 \mathrm{~h}$ & ? & 275 & $130-550$ \\
\hline at $2400 \mathrm{~h}$ & ? & 113 & $55-415$ \\
\hline Aldosterone (pmol/1) & 3120 & 719 & $150-3000$ (infants) \\
\hline Renin activity (pmol/ml per hour) & $29 \cdot 3$ & $14 \cdot 0$ & 3-5 (infants) \\
\hline 17-OH-progesterone $(\mathrm{mmol} / \mathrm{l})$ & $120 \cdot 0$ & 33 & $<15$ \\
\hline
\end{tabular}

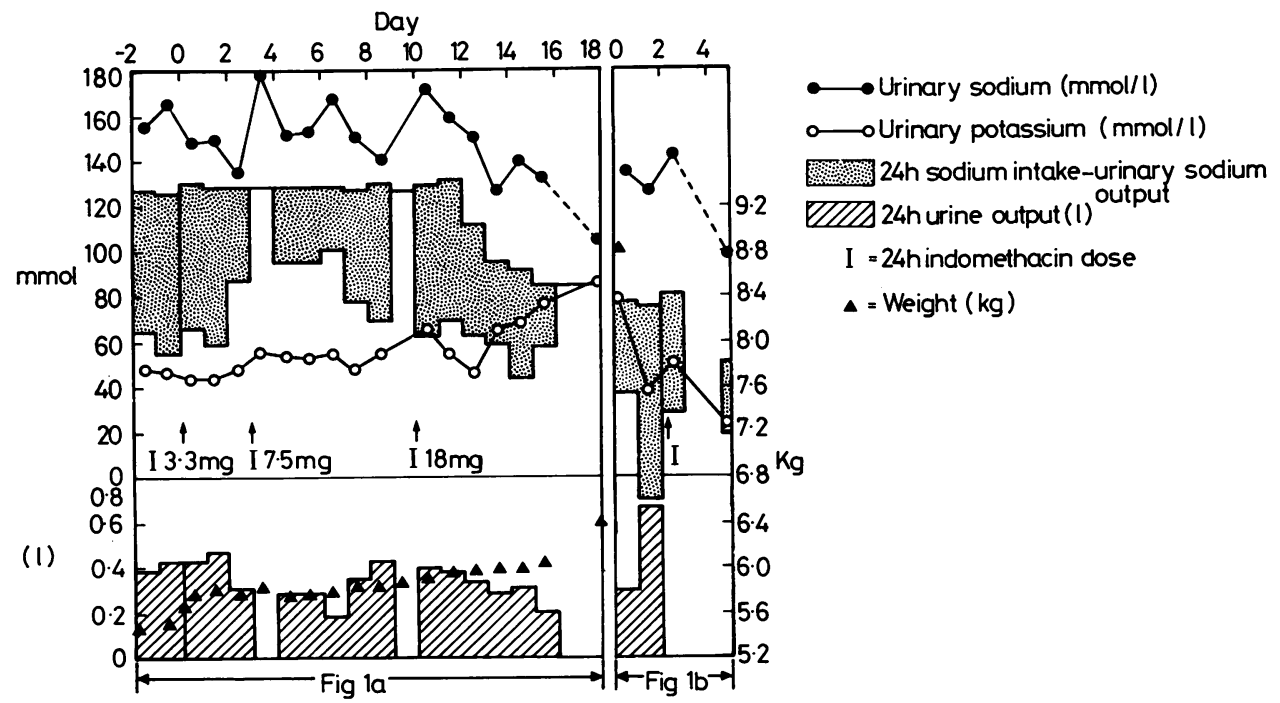

Figure Effect of indomethacin on renal water and electrolyte excretion (a) at first admission (b) at second admission.

osmotic diuresis was eventually compensated by large intakes of sodium $25 \mathrm{mmol} / \mathrm{kg}$ and fluid (milk) $200 \mathrm{ml} / \mathrm{kg}$ daily. His balance remained precarious however, so indomethacin was started to try to facilitate control (Fig. 1a). After a transient response to smaller doses, $1 \mathrm{mg} / \mathrm{kg}$ three times daily resulted in reduced sodium and fluid requirements after 48 hours, with improved potassium excretion and a slight drop in BP from $110 / 60$ to $100 / 60 \mathrm{mmHg}$. Plasma indomethacin was $0.8 \mathrm{mg} / \mathrm{l}$ (adult therapeutic range $1-3 \mathrm{mg} / \mathrm{l}$ ). Blood urea and serum creatinine levels remained normal. Four days later he became fluid overloaded, with plasma aldosterone reduced to $590 \mathrm{pmol} / \mathrm{l}$ and plasma renin activity (PRA) reduced to $5 \cdot 35 \mathrm{pmol} / \mathrm{ml}$ per hour. Daily sodium and fluid intakes were reduced to $8 \mathrm{mmol} / \mathrm{kg}$ and $150 \mathrm{ml} / \mathrm{kg}$ respectively. He was discharged on indomethacin, weighing $6.4 \mathrm{~kg}$.

On review at age 18 months he had required a few brief admissions for vomiting. BP was $100 / 60 \mathrm{mmHg}$. He had been receiving $2.1 \mathrm{mg} / \mathrm{kg}$ daily indomethacin with a sodium intake up to $9 \mathrm{mmol} / \mathrm{kg}$. PRA was $22.4 \mathrm{pmol} / \mathrm{ml}$ per hour, plasma aldosterone 840 $\mathrm{pmol} / \mathrm{l}$, and aspartate transaminase $58 \mathrm{IU} / \mathrm{l}$ (normal $<40)$. His length $(74.7 \mathrm{~cm})$ and weight $(8.8 \mathrm{~kg})$ were just below the 3 rd centile but were appropriate as his parents were small.

When indomethacin was stopped without altering 
sodium or fluid intake, he entered negative sodium balance within 48 hours and became dehydrated (Fig. 1b). The pseudohypoaldosteronism (PHA) had clearly not remitted so he was discharged on indomethacin $2 \mathrm{mg} / \mathrm{kg}$ daily with sodium $6 \mathrm{mmol} / \mathrm{kg}$, and fluid about $120 \mathrm{ml} / \mathrm{kg}$.

\section{Discussion}

This patient differs from others previously reported by the severity of his osmotic diuresis and by his maintenance treatment with indomethacin. The pattern of response raises questions about the pathophysiology of PHA.

Since 1958, 42 cases of PHA have been described. ${ }^{1}$ Common features have been vomiting, lethargy, and failure to thrive from early infancy; there is saltwasting and hyperkalaemia with raised levels of plasma aldosterone and PRA. ${ }^{1-4}$ Most cases have presented with natriuresis, but one report demonstrated multiple aldosterone end-organ resistance, and another showed only sweat and salivary gland insensitivity. ${ }^{3}$ Control has been achieved by large dietary sodium supplements. ${ }^{1-4}$ Some cases have been familial. ${ }^{12}$

(1) Aldosterone end-organs. The membrane-bound enzyme system $\mathrm{Na}$, K-ATPase, is normally stimulated by an increased sodium work load on the nephron. ${ }^{4}$ Support was therefore given to the concept of intrinsic tubular abnormality when Bierich and Schmidt found deficient Na, K-ATPase activity throughout the renal tubule in a case of PHA. ${ }^{4}$ At least distal tubular aldosterone insensitivity must be present to explain the hyperkalaemia; effects of aldosterone on the proximal tubule are controversial. ${ }^{6}$ Further evidence for end-organ resistance is given by involvement of other aldosterone targets in $\mathrm{PHA}^{3}$ and by its resistance to exogenous mineralocorticoids. ${ }^{1}$

(2) Renin-aldosterone axis. Raised aldosterone levels could be explained partly by a direct positive feedback from the end-organ or from hyperkalaemia, and partly by activation of the RA-Aldos axis in response to impaired renal perfusion. ${ }^{5}$ Excess PRA is reflected in hyperplasia of the juxtaglomerular apparatus in PHA. ${ }^{4}$ In our patient, raised plasma 17-OH progesterone and aldosterone (Table) in a salt-depleted state supports an increased reninaldosterone drive, rather than an 18-oxidation defect. Urinary adrenal androgen and corticosterone metabolites were also slightly raised in the depleted state.

(3) Prostaglandins. The renal PGs were first incriminated in PHA by Rampini et al. ${ }^{2}$ Their patient had less natriuresis during a 4-day course of indomethacin. Renal PGs E1 and E2 promote vasodilatation, saliuresis, kaliuresis, and hydromosis. During hypovolaemia, they probably contribute to renovascular homeostasis by redistributing blood to the juxtamedullary nephrons, which are in fact predominantly natriuretic. ${ }^{5} \mathrm{PGE}_{2}$ inhibits $\mathrm{Na}$, K-ATPase ${ }^{5}$ so its overactivity would partly explain the findings of Bierich and Schmidt. ${ }^{4}$ Water loss is promoted by $\mathrm{PGE}_{1}$ through inhibition of cyclicAMP-mediated collecting duct sensitivity to vasopressin and $\mathrm{PGE}_{2}$ can stimulate the RA-Aldos system. ${ }^{6}$

PHA involves multiple, complex interactions between aldosterone end-organs, renal PGs, and the RA-Aldos system, creating a vicious circle. Saltwasting seems to persist in adulthood but the tendency to negative sodium balances is ameliorated by age 2 years in most cases, possibly through the combined effects of an improved salt appetite and maturation of end-organ ATP-ase function. ${ }^{1-4}$ The persistently raised PRA at 18 months in our patient illustrates that, although the clinical effects of PHA were controlled, biochemical compensation remained incomplete.

The potential toxicity of indomethacin precludes its recommendation for routine treatment of PHA (our patient's AST levels, for example, were slightly raised) but in severe, life-threatening cases it may be a valuable adiunct to sodium supplementation.

We thank Dr W Schutt and Dr R Prosser for referring this patient to us.

\section{References}

1 Dillon M J, Leonard J V, Buckler J M, et al. Pseudohypoaldosteronism. Arch Dis Child 1980; 55 : 427-34.

2 Rampini S, Furrer J, Keller H P, Bucher H, Zachmann M. Congenital pseudohypoaldosteronism: case report and review. Helv Paediatr Acta 1978; 33: 153-67.

3 Oberfield S E, Levine L S, Carey R M, Bejar R, New M I. Pseudohypoaldosteronism: multiple target organ unresponsiveness to mineralocorticoid hormones. $J$ Clin Endocrinol Metab 1979; 48: 228-34.

4 Bierich J R, Schmidt U. Tubular Na, K-ATPase deficiency, the cause of the congenital renal salt-losing syndrome. Eur J Pediatr 1976; 121 : 81-7.

5 Lee J B, Patak R V, Mookerjee B K. Renal prostaglandins and the regulation of blood pressure and sodium and water homeostasis. Am J Med 1976; 60: 798-816.

6 Anonymous. Prostaglandins in the kidney. Lancet 1981; ii: $343-5$.

Correspondence to $\mathrm{Dr} M$ Bommen, Department of Paediatrics, The Middlesex Hospital, Mortimer Street, London WIN 8AA.

Received 10 March 1982 